\title{
Occupational exposures and changes in pulmonary function over 13 years among residents of Cracow
}

\author{
M KRZYŻANOWSKI, ${ }^{1}$ W JEDRYCHOWSKI, ${ }^{2}$ M WYSOCKI ${ }^{1}$ \\ From the Department of Medical Statistics, 'National Institute of Hygiene, Warsaw, and Department of \\ Epidemiology, ${ }^{2}$ Medical School of Cracow, Cracow, Poland
}

\begin{abstract}
In a 13 year follow up study conducted among residents of Cracow the relation of annual rate of decline in $\mathrm{FEV}_{1}$ to occupational exposures was analysed. The study group consisted of 696 men and 983 women aged $19-60$ at the start of the study in 1968. They were interviewed three times, in 1968, 1973, and 1981, and decline in $\mathrm{FEV}_{1}$ was estimated for each subject from spirometric measurements in 1968 and 1981 . The interviews provided data on exposure at the workplace to dusts, variable temperature, and chemicals or irritating gases, which established duration and time of the exposure. The FEV $\mathrm{FE}_{1}$ mean level, height, and smoking habits were considered as confounders in the analysis. The study indicated that the most pronounced influence on decline in $\mathrm{FEV}_{1}$ was prolonged and continuing exposure to variable temperature. The effects of dusts, independent of exposure to variable temperature, were much smaller but analysis in occupational subgroups suggest that dust may be important in some, such as workers in the building materials and pottery industry. Relatively immediate effects of exposure to chemicals were detected independently of effects of other exposures. The estimated effects of occupational exposures were of a similar magnitude as those of tobacco smoking though related to much smaller groups. Both effects were additive in accelerating decline in lung function. These results, obtained in the general population and less biased by selection than studies performed in industrial settings, show the importance of occupational factors in the natural history of limitation of airflow.
\end{abstract}

The importance of occupational exposures as a causative factor related to chronic airflow limitation has been questioned by several authors. ${ }^{12}$ Cross sectional studies, often biased by selection of workers into the workplace, the so called "healthy worker effect," do not provide sufficient evidence for such a conclusion. Interest in the possible contribution of occupational hazards to the development of airflow limitation has been greatly strengthened by the results of several longitudinal studies, reviewed recently by Becklake. ${ }^{3}$ Published studies have been based on industrial populations, usually in unfavourable working environments, such as coal miners or foundry workers. By analysing changes in lung function instead of dealing with its level, it is easier to reduce the healthy worker effect in industrial studies, but some bias caused by selection into the industry-and to the studied populations-might influence the relation between occupational exposure and airflow limitation.

The present study is based on data from a 13 year

Accepted 21 September 1987 follow up of a general population sample. Analysis of these data has indicated a faster rate of decline in lung function among men and women reporting ever having worked with dusts or at variable temperature. ${ }^{4}$ We consider the role of type, time, and duration of exposure in more detail.

\section{Material and methods}

The longitudinal study of chronic obstructive pulmonary diseases in Cracow is based on a random sample of residents of the city aged from 19 to 70 at the first survey in 1968.5 The study group was followed up and examined in 1973 and 1981 . Because of a relatively poor follow up rate in the oldest subjects, ${ }^{46}$ we restricted the analysis to subjects aged 19-60 at entry. Of the 3843 men and women in the sample, 2678 respondents $(70 \%)$ had spirometry measured during the baseline survey. Larger percentages, in men up to $75 \%(p<0.05)$ were found among those who, in 1968 , had been occupationally exposed to dusts or to variable temperatures for at least five years than in the 
Table 1 Mean baseline FEV in subjects examined and not examined in 1981 by occupational exposures $\dagger$

\begin{tabular}{|c|c|c|c|c|c|c|c|c|c|}
\hline \multirow[b]{3}{*}{ Status in 1981} & \multirow[b]{3}{*}{ No } & \multirow[b]{3}{*}{$\%$} & \multirow{3}{*}{$\begin{array}{l}\text { Mean } \\
F E V \text { § }\end{array}$} & \multicolumn{6}{|c|}{ Exposed to } \\
\hline & & & & \multicolumn{2}{|l|}{ Dusts } & \multicolumn{2}{|c|}{ Variable temperature } & \multicolumn{2}{|l|}{ Chemicals } \\
\hline & & & & $\%$ & $F E V$ § & $\%$ & $F E V \S$ & $\%$ & $F E V, \S$ \\
\hline $\begin{array}{l}\text { Men: } \\
\text { Analysed group } \\
\text { Dead } \\
\text { Others } \ddagger\end{array}$ & $\begin{array}{l}696 \\
134 \\
363\end{array}$ & $\begin{array}{l}58 \cdot 3 \\
11 \cdot 2 \\
30 \cdot 4\end{array}$ & $\begin{array}{l}4.01 \\
3.66^{* *} \\
4.02\end{array}$ & $\begin{array}{l}62 \cdot 2 \\
16 \cdot 2 \\
21 \cdot 5\end{array}$ & $\begin{array}{l}3.99 \\
3.66 * * \\
3.89\end{array}$ & $\begin{array}{l}68.0 \\
12.4 \\
19 \cdot 6\end{array}$ & $\begin{array}{l}3.96 \\
3.55^{* *} \\
3.91\end{array}$ & $\begin{array}{l}62 \cdot 9 \\
14 \cdot 3 \\
22 \cdot 8\end{array}$ & $\begin{array}{l}4.01 \\
3.67^{* *} \\
3.99\end{array}$ \\
\hline All with spirometry in 1968 & 1193 & $100 \cdot 0$ & 3.98 & $\begin{array}{l}100 \cdot 0 \\
(n=270)\end{array}$ & 3.91 & $\begin{array}{l}100 \cdot 0 \\
(n=225)\end{array}$ & 3.90 & $\begin{array}{l}100 \cdot 0 \\
(n=224)\end{array}$ & 3.97 \\
\hline $\begin{array}{l}\text { Women: } \\
\text { Analysed group } \\
\text { Dead } \\
\text { Others } \ddagger\end{array}$ & $\begin{array}{r}983 \\
65 \\
437\end{array}$ & $\begin{array}{r}66 \cdot 2 \\
4 \cdot 4 \\
29 \cdot 4\end{array}$ & $\begin{array}{l}2.91 \\
2.75^{* *} \\
2.87\end{array}$ & $\begin{array}{r}64.4 \\
5.7 \\
29.9\end{array}$ & $\begin{array}{l}2.89 \\
2.74 \\
2 \cdot 77\end{array}$ & $\begin{array}{r}66 \cdot 3 \\
7 \cdot 1 \\
26 \cdot 5\end{array}$ & $\begin{array}{l}2 \cdot 86 \\
2 \cdot 71^{*} \\
2 \cdot 60^{* *}\end{array}$ & $\begin{array}{r}70.6 \\
9.5 \\
19.8\end{array}$ & $\begin{array}{l}2.92 \\
2 \cdot 52^{* *} \\
2 \cdot 67^{* *}\end{array}$ \\
\hline All with spirometry in 1968 & 1485 & $100 \cdot 0$ & 2.89 & $\begin{array}{l}100 \cdot 0 \\
(n=174)\end{array}$ & $2 \cdot 84$ & $\begin{array}{l}100 \cdot 0 \\
(n=98)\end{array}$ & $2 \cdot 76$ & $\begin{array}{l}100 \cdot 0 \\
(n=126)\end{array}$ & $2 \cdot 84$ \\
\hline
\end{tabular}

$* 0.05<\mathrm{p}<0.10 ; *$ * $<0.05$ in relation to analysed group.

IIn 1968 for five years or more.

+Not interviewed in 1973 or 1981, not examined spirometrically in 1981, or lost to follow up.

$\$ 1$ In 1968 age and height adjusted, in litres.

non-exposed. Among those aged 19-60 with spirometry measured, 199 died during the 13 year follow up period (table 1). Complete data from three interviews and at least baseline and final spirometric examinations are available on $696 \mathrm{men}$ and 983 women aged 19-60, and the analysis presented below is based on this group. All these men and most (94\%) women were occupationally active in or sometime before 1981. The proportion analysed-that is, with complete data-among all women with spirometry measured in 1968 was similar in those reporting and not reporting occupational exposure in 1968. In the men, however, the proportion analysed was significantly $(p<0.01)$ greater among those exposed to variable temperature $(68 \%)$ than in those not exposed $(55 \%)$. In the analysed group the age and height adjusted FEV $_{1}$ values in the baseline examination were slightly higher than in all those examined in 1968. This was mainly due to a lower $\mathrm{FEV}_{1}$ in subjects who subsequently died. ${ }^{6}$ In women exposed to variable temperature or to chemicals, however, the FEV $_{1}$ was also significantly $(p<0.01)$ higher in the analysed group than in the living subjects who were not followed up-that is, in the "others" category.

Interviews were carried out by trained interviewers using a questionnaire based on that developed by the British Medical Research Council. The information on occupational exposure was collected in the interviews by sets of questions concerning type (dusts, variable temperature: heat and cold, chemicals, or irritating gases), duration (in years before 1968), and time of exposure (before baseline survey, present at the time of the survey in 1968 , or present at the follow up survey in 1973). The baseline interview also contained a question on type of workplace, including branch of industry, and in the final examination the respondents were asked to characterise more exactly the type of chemicals or dusts ever present in their working environment. No independent assessment of working conditions was performed.

All those interviewed were invited to take part in clinical examinations including spirometric tests performed with the Vitalograph wedge spirometer. The examination procedure was the same in the baseline and in the final study and has been reported elsewhere. ${ }^{4}$ The changes of FEV (corrected to BTPS) over 13 years of follow up were calculated as a difference between the baseline and final results and expressed in ml a year. Age and height adjusted FEV was calculated using linear regression equations estimated separately for all with spirometry measured in 1968 (men and women separately) and corresponds to age 40 and height $170 \mathrm{~cm}$ (men) or $160 \mathrm{~cm}$ (women).

In the data analysis we used linear regression methods with dummy variables representing particular categories of categorical factors. The regression models allowed us to adjust the analysed associations for possible confounding factors detected in previous analysis,${ }^{4}$ including smoking history and

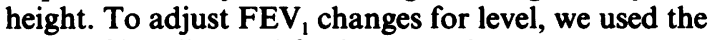
mean of baseline and final FEV, values.

\section{Results}

At the first survey in $1968,36.9 \%$ of the men and $18.6 \%$ of the women reported having worked in one or more of the considered types of exposure for at least five years. At the time of the follow up survey in 1973, $54.6 \%$ of the analysed men and $28.9 \%$ of the women 
Table 2 Combined exposures to dust, variable temperature, and chemicals in 1973 (number of subjects)

\begin{tabular}{lllrl}
\hline Dust & $\begin{array}{l}\text { Variable } \\
\text { temp }\end{array}$ & Chemicals & Men & Women \\
\hline No & No & No & 316 & 699 \\
Yes & No & No & 55 & 73 \\
No & Yes & No & 48 & 46 \\
No & No & Yes & 57 & 67 \\
Yes & Yes & No & 43 & 22 \\
Yes & No & Yes & 42 & 28 \\
No & Yes & Yes & 31 & 23 \\
Yes & Yes & Yes & 104 & 25 \\
Total & & & 696 & 983 \\
\hline
\end{tabular}

reported exposure. Over $57 \%$ of the exposed men and $34 \%$ of the exposed women worked in more than one type of unfavourable environment (table 2). Most men reported long exposure that continued to the follow up period (table 3) whereas most women reported exposure present only during the follow up (table 4). Most women reporting exposure in 1968 were not exposed in 1973.

The age and height adjusted baseline $\mathrm{FEV}_{1}$ level was similar in men with a history of occupational exposures and in unexposed men. In women the FEV level was related to the history of exposure to dust. A relatively low $\mathrm{FEV}_{1}$ was observed in those reporting long exposure present at the 1968 survey but not continuing in the follow up period. Women exposed for over five years in 1968 and still working in dusty conditions in 1973 had baseline FEV, levels above the average.

In most people with a history of occupational exposure the crude decline in FEV , was greater than in the unexposed group. The age structure and proportion of cigarette smokers differed in the exposed compared with the unexposed and, as these factors are related to the rate of FEV loss, we had to take them into account in further analysis. The adjustment for age gave similar results to the adjustment for mean FEV $_{1}$ level both as concerns the size of estimated effects and their importance. Therefore we present only the results of the latter method of adjustment.

The strongest effect of exposures to dusts and variable temperature on decline in $\mathrm{FEV}_{1}$, adjusted for smoking and $F E V_{1}$ level, was from exposure lasting for at least five years before the baseline study and present during the follow up period (table 5). Effects of similar size, though not statistically significant, were estimated for all other men reporting exposure to dust in 1973. A relatively fast decline was also found in women working in dust only in the past (before the first survey), whereas in those reporting long exposure at the time of the first survey but not working in a dusty environment in 1973, the decline in $\mathrm{FEV}_{1}$ was smaller than average. Less than five years exposure to variable temperature before 1968 but continued into the follow up period also accelerated the decline in FEV $_{1}$. Exposure to chemicals was associated with accelerated decline in FEV in men when the exposure was present in 1968 even for a short time and continued in the follow up period. In women a significant effect was found only in those reporting exposure for the first time in 1973.

As all three types of exposure were intercorrelated, we considered all types of exposure jointly. Based on the models which estimated particular types of exposure separately, we included in the regression models all indicator variables corresponding to categories found to be at least marginally significant and to non-significant categories but with the estimated effects of the value at least equal to the smallest significant coefficient. With negligible change in the size of estimated effects and no change in their significance, the regression models could be reduced to the form presented in table 6 , where the latter elements were eliminated from the equations. In both men and women the significant effect independent of other

Table 3 Mean baseline FEV, and observed annual rate of $F E V_{1}$ decline in men by history of occupational exposure to particular factors

\begin{tabular}{|c|c|c|c|c|c|c|c|c|c|c|}
\hline \multicolumn{2}{|l|}{ History of exposure } & \multicolumn{3}{|l|}{ Dusts } & \multicolumn{3}{|c|}{ Variable temperature } & \multicolumn{3}{|c|}{ Chemicals } \\
\hline 1968 & 1973 & $\begin{array}{l}F E V_{1} \dagger \\
N o\end{array}$ & $\underset{(l)}{\Delta F E V_{1}}$ & $(m l / y)$ & $\begin{array}{l}F E V_{1} \dagger \\
N o\end{array}$ & $\begin{array}{l}\Delta F E V_{1} \\
(l)\end{array}$ & $(m l / y)$ & $\begin{array}{l}F E V_{1} \dagger \\
N o\end{array}$ & $\underset{(l)}{\Delta F E V_{1}}$ & $(m l / y)$ \\
\hline $\begin{array}{l}\geqslant 5 \text { years } \\
1-4 \text { years } \\
\geqslant 5 \text { years } \\
\text { only in the past } \\
\text { Only in } 1973 \\
\text { Not exposed } \$\end{array}$ & $\begin{array}{l}\text { Yes } \\
\text { No } \\
\text { Yes } \\
\text { No } \\
\text { Yes } \\
\text { No }\end{array}$ & $\begin{array}{r}126 \\
42 \\
30 \\
22 \\
8 \\
22 \\
80 \\
366\end{array}$ & $\begin{array}{l}3 \cdot 99 \\
4 \cdot 00 \\
3.94 \\
3 \cdot 87 \\
3 \cdot 78 \\
3 \cdot 89 \\
4 \cdot 02 \\
4 \cdot 05\end{array}$ & $\begin{array}{l}63 \cdot 0 \\
66 \cdot 5 \\
67 \cdot 0 \\
55 \cdot 1 \\
69 \cdot 7 \\
59 \cdot 4 \\
59 \cdot 6 \\
52 \cdot 5\end{array}$ & $\begin{array}{r}100 \\
53 \\
20 \\
24 \\
6 \\
17 \\
100 \\
376\end{array}$ & $\begin{array}{l}4 \cdot 04 \\
3.82 \\
3.95 \\
4 \cdot 12 \\
3 \cdot 82 \\
4 \cdot 11 \\
3.93 \\
4 \cdot 05\end{array}$ & $\begin{array}{l}69 \cdot 1 \\
52 \cdot 1 \\
65 \cdot 6 \\
56 \cdot 2 \\
67 \cdot 4 \\
50 \cdot 3 \\
54 \cdot 3 \\
55 \cdot 3 \\
*\end{array}$ & $\begin{array}{r}102 \\
39 \\
30 \\
19 \\
6 \\
19 \\
96 \\
385\end{array}$ & $\begin{array}{l}4 \cdot 05 \\
4 \cdot 00 \\
4 \cdot 16 \\
4 \cdot 06 \\
3 \cdot 57 \\
3 \cdot 96 \\
3 \cdot 91 \\
4 \cdot 03\end{array}$ & $\begin{array}{l}64.5 \\
55 \cdot 8 \\
73 \cdot 7 \\
64 \cdot 1 \\
69 \cdot 0 \\
64.6 \\
55 \cdot 6 \\
53 \cdot 6\end{array}$ \\
\hline Total & & 696 & $4 \cdot 01$ & $57 \cdot 1$ & 696 & $4 \cdot 01$ & $57 \cdot 2$ & 696 & $4 \cdot 01$ & $57 \cdot 2$ \\
\hline
\end{tabular}

$0.05<\mathrm{p}<0.10$.

tIn 1968 age and height adjusted.

$\$$ Never exposed or exposed only in the past, before 1968 , for less than five years. 
Table 4 Mean baseline FEV $V_{1}$ and observed annual rate of FEV decline in women by history of occupational exposure to particular factors

\begin{tabular}{|c|c|c|c|c|c|c|c|c|c|c|}
\hline \multicolumn{2}{|c|}{ History of exposure } & \multicolumn{3}{|c|}{ Dusts } & \multicolumn{3}{|c|}{ Variable temperature } & \multicolumn{3}{|c|}{ Chemicals } \\
\hline 1968 & 1973 & No & $\underset{(l)}{F E V_{1} \dagger}$ & $\begin{array}{l}\Delta F E V_{1} \\
(m l / y)\end{array}$ & No & $\underset{(l)}{F E V_{1} \dagger}$ & $\begin{array}{l}\Delta F E V_{1} \\
(\mathrm{ml} / \mathrm{y})\end{array}$ & No & $\underset{(l)}{F E V_{1} \dagger}$ & $\begin{array}{l}\Delta F E V, \\
(\mathrm{ml} / \mathrm{y})\end{array}$ \\
\hline $\begin{array}{l}\geqslant 5 \text { years } \\
1-4 \text { years } \\
\geqslant 5 \text { years } \\
\text { only in the past } \\
\text { Only in } 1973 \\
\text { Not exposed } f\end{array}$ & $\begin{array}{l}\text { Yes } \\
\text { No } \\
\text { Yes } \\
\text { No } \\
\text { Yes } \\
\text { No }\end{array}$ & $\begin{array}{r}50 \\
62 \\
19 \\
47 \\
2 \\
12 \\
77 \\
714\end{array}$ & $\begin{array}{l}3.05 \\
2.76 \\
2.89 \\
2.93 \\
3.16 \\
2.78 \\
2.93 \\
2.91 \\
* *\end{array}$ & $\begin{array}{l}48 \cdot 0 \\
33 \cdot 1 \\
29 \cdot 3 \\
36 \cdot 8 \\
37 \cdot 4 \\
57 \cdot 7 \\
35 \cdot 4 \\
38 \cdot 7 \\
* *\end{array}$ & $\begin{array}{r}25 \\
40 \\
15 \\
26 \\
3 \\
9 \\
73 \\
792\end{array}$ & $\begin{array}{l}2.88 \\
2.84 \\
3.06 \\
3.00 \\
3.29 \\
2.96 \\
2.95 \\
2.90\end{array}$ & $\begin{array}{l}56 \cdot 9 \\
40 \cdot 2 \\
50 \cdot 2 \\
30 \cdot 2 \\
46 \cdot 9 \\
36 \cdot 8 \\
43 \cdot 7 \\
37 \cdot 4 \\
* * *\end{array}$ & $\begin{array}{r}52 \\
37 \\
13 \\
31 \\
4 \\
14 \\
74 \\
758\end{array}$ & $\begin{array}{l}2.90 \\
2.96 \\
2.92 \\
2.83 \\
3.23 \\
2.87 \\
2.96 \\
2.91\end{array}$ & $\begin{array}{l}43 \cdot 2 \\
39 \cdot 0 \\
36 \cdot 7 \\
41 \cdot 0 \\
31 \cdot 4 \\
35 \cdot 8 \\
45 \cdot 8 \\
37 \cdot 4\end{array}$ \\
\hline Total & & 983 & 2.91 & $38 \cdot 5$ & 983 & 2.91 & $38 \cdot 5$ & 983 & 2.91 & $38 \cdot 5$ \\
\hline
\end{tabular}

***p $<0.01 ; * 0.01<\mathrm{p}<0.05$.

IIn 1968 age and height adjusted.

$\ddagger$ Never exposed or exposed only in the past, before 1968 , for less than five years.

exposures, was that of variable temperatures present for over five years in 1968 and continued during follow up. When this exposure stopped, the decline in FEV levelled off. In men the effect of exposure to chemicals during the follow up period but lasting not more than four years before the baseline survey was even greater. In women the effect of chemicals could be detected only in those exposed during the follow up period. The effect of exposure to dust was not significant in men. In women decline in $\mathrm{FEV}_{1}$ was above average in those exposed for five years or longer only in the past, before the first survey, but in women exposed during that survey and not in 1973 the decrease of $\mathrm{FEV}_{1}$ was slower than average. In both categories of women the baseline $\mathrm{FEV}_{1}$ level was relatively low, so we cannot attribute these rather inconsistent results to inadequate adjustments for $\mathrm{FEV}_{1}$ level in the analysis.

We found no significant interactions between indicators of exposure and cigarette smoking. This suggests that the effects of both factors are additive. The absolute values of estimated significant effects of occupational exposure even exceeded, though not significantly, the effect of cigarette smoking continued over the follow up period. The standard errors of the regression coefficients were greater in the case of the exposures than for smoking, suggesting that the effects of exposures are not uniform. To identify subgroups possibly with changes in $F E V_{1}$ different from those expected, and to validate our regression equations, we performed an analysis of residuals. The expected decline in $\mathrm{FEV}_{1}$ was calculated using the equations shown in table 6 . We tabulated the means of residuals by category of workplace, reported in 1968 as the present or the last one (table 7). Only men working in the building materials and pottery industry had a significantly greater than expected decline in $\mathrm{FEV}_{1}$. In

Table 5 Effects of occupational exposures on decline in $F E V_{1}(\mathrm{ml} / \mathrm{y})$ estimated in multiple linear regression $\dagger$

\begin{tabular}{|c|c|c|c|c|c|c|c|}
\hline \multicolumn{2}{|c|}{ History of exposure } & \multicolumn{2}{|l|}{ Dusts } & \multicolumn{2}{|c|}{ Variable temperature } & \multicolumn{2}{|l|}{ Chemicals } \\
\hline 1968 & 1973 & $b$ & $S E_{b}$ & $b$ & $S E_{b}$ & $b$ & $S E_{b}$ \\
\hline \multicolumn{8}{|c|}{ Men } \\
\hline $\begin{array}{l}\geqslant 5 \text { years } \\
1-4 \text { years } \\
\geqslant 5 \text { years } \\
\text { only in the past } \\
\text { Only in } 1973\end{array}$ & $\begin{array}{l}\text { Yes } \\
\text { No } \\
\text { Yes } \\
\text { No } \\
\text { Yes } \\
\text { No }\end{array}$ & $\begin{array}{c}7 \cdot 1 * \\
10.2 \\
11 \cdot 1 \\
2 \cdot 3 \\
9.0 \\
0.0 \\
7 \cdot 4\end{array}$ & $\begin{array}{r}4 \cdot 1 \\
6 \cdot 4 \\
7 \cdot 5 \\
8 \cdot 6 \\
14 \cdot 1 \\
8 \cdot 6 \\
4 \cdot 9\end{array}$ & $\begin{array}{c}11 \cdot 0^{* * *} \\
-6 \cdot 3 \\
12.4 \\
2.9 \\
0.9 \\
-7.8 \\
-2.2\end{array}$ & $\begin{array}{r}4 \cdot 5 \\
5 \cdot 8 \\
9 \cdot 0 \\
8 \cdot 3 \\
16 \cdot 2 \\
9 \cdot 7 \\
4 \cdot 4\end{array}$ & $\begin{array}{c}9 \cdot 9 * * \\
2 \cdot 8 \\
24 \cdot 4^{* * * *} \\
9 \cdot 1 \\
1 \cdot 3 \\
6 \cdot 3 \\
1 \cdot 3\end{array}$ & $\begin{array}{r}4 \cdot 4 \\
6 \cdot 6 \\
7 \cdot 4 \\
9 \cdot 2 \\
16 \cdot 1 \\
9 \cdot 2 \\
4 \cdot 5\end{array}$ \\
\hline \multicolumn{8}{|c|}{ Women } \\
\hline $\begin{array}{l}\geqslant 5 \text { years } \\
1-4 \text { years } \\
\geqslant 5 \text { years } \\
\text { only in the past } \\
\text { Only in } 1973\end{array}$ & $\begin{array}{l}\text { Yes } \\
\text { No } \\
\text { Yes } \\
\text { No } \\
\text { Yes } \\
\text { No }\end{array}$ & $\begin{array}{l}9 \cdot 3^{* * *} \\
-7 \cdot 8^{* * *} \\
-7 \cdot 6 \\
-2 \cdot 5 \\
-4 \cdot 3 \\
16.9 * * \\
-2 \cdot 3\end{array}$ & $\begin{array}{r}4 \cdot 2 \\
3 \cdot 8 \\
6 \cdot 7 \\
4 \cdot 3 \\
20 \cdot 3 \\
8 \cdot 4 \\
8 \cdot 4 \\
3 \cdot 5\end{array}$ & $\begin{array}{c}17 \cdot 4^{* * *} \\
0.9 \\
14 \cdot 0^{*} \\
-5 \cdot 2 \\
11 \cdot 1 \\
-0.3 \\
6.8^{*}\end{array}$ & $\begin{array}{r}5 \cdot 8 \\
4 \cdot 7 \\
7 \cdot 5 \\
5.7 \\
16 \cdot 6 \\
9 \cdot 6 \\
3 \cdot 5\end{array}$ & $\begin{array}{r}5 \cdot 4 \\
1 \cdot 0 \\
1 \cdot 3 \\
4 \cdot 0 \\
-4 \cdot 7 \\
-3 \cdot 1 \\
8 \cdot 5 * * *\end{array}$ & $\begin{array}{r}4 \cdot 1 \\
4 \cdot 8 \\
8 \cdot 1 \\
5 \cdot 3 \\
14 \cdot 5 \\
7 \cdot 8 \\
3 \cdot 5\end{array}$ \\
\hline
\end{tabular}

tConfounders: height, mean level of ventilatory function; smoking in 1968, 1973, and 1981; giving up smoking between 1968 and 1981 . The effects of occupational exposure were estimated in relation to the "not exposed" group.

${ }^{* * *} \mathrm{p}<0.01 ;{ }^{*} 0.01<\mathrm{p}<0.05 ;{ }^{*} 0.05<\mathrm{p}<0.10$. 
Table 6 Effects of occupational exposures considered jointly in the regression equation on decline in FEV $(\mathrm{ml} / \mathrm{y})$

\begin{tabular}{|c|c|c|c|c|c|c|}
\hline \multirow[b]{2}{*}{ Factor } & & & \multicolumn{2}{|l|}{ Men } & \multicolumn{2}{|l|}{ Women } \\
\hline & & & $\boldsymbol{b}$ & $S E_{b}$ & $\boldsymbol{b}$ & $S E_{b}$ \\
\hline $\begin{array}{l}\text { Exposure to: } \\
\text { Dusts } \\
\text { Variable temperatures } \\
\text { Chemicals }\end{array}$ & $\begin{array}{l}\text { In } 1968 \\
\geqslant 5 \text { years } \\
\geqslant 5 \text { years } \\
\text { only in the past } \\
\geqslant 5 \text { years } \\
1-4 \text { years } \\
\text { only in the past } \\
\geqslant 5 \text { years } \\
1-4 \text { years } \\
\text { only in the past }\end{array}$ & $\begin{array}{l}\text { In } 1973 \\
\text { Yes } \\
\text { No } \\
\text { No } \\
\text { Yes } \\
\text { Yes } \\
\text { No } \\
\text { Yes } \\
\text { Yes } \\
\text { No }\end{array}$ & $\begin{array}{l}-1 \cdot 7 \\
= \\
= \\
- \\
-^{5.11 .8 * *} \\
24 \cdot 4 * *\end{array}$ & $\begin{array}{l}4 \cdot 7 \\
7 \cdot 3\end{array}$ & $\begin{array}{c}5 \cdot 7 \\
-7.0^{*} \\
16 \cdot 0^{*} \\
15 \cdot 4^{* *} \\
11 \cdot 3 \\
4 \cdot 4 \\
-\quad \\
\\
6.3 *\end{array}$ & $\begin{array}{l}4 \cdot 4 \\
3 \cdot 8 \\
8 \cdot 4 \\
6 \cdot 1 \\
7 \cdot 5 \\
3.6 \\
\end{array}$ \\
\hline \multicolumn{3}{|c|}{$\begin{array}{l}\text { Mean level of FEV }(\mathrm{dcl}) \\
\text { Height }(\mathrm{cm}) \\
\text { Cigarette smoking in 1968, 1973, and } 1981 \\
\text { Giving up smoking between } 1968 \text { and } 1981\end{array}$} & $\begin{array}{r}-1 \cdot 4 * * * \\
1.8 * * * \\
8 \cdot 4^{* * * *} \\
15 \cdot 1 * * *\end{array}$ & $\begin{array}{l}0 \cdot 2 \\
0 \cdot 3 \\
3 \cdot 3 \\
4 \cdot 3\end{array}$ & $\begin{array}{l}-0.8 * * * \\
0 \cdot 5 * * * \\
4 \cdot 8 * * \\
-0.7\end{array}$ & $\begin{array}{l}0 \cdot 2 \\
0 \cdot 2 \\
2 \cdot 4 \\
4 \cdot 0\end{array}$ \\
\hline \multicolumn{3}{|l|}{$\mathbf{R}^{2}(\%)$} & $12 \cdot 4$ & & $5 \cdot 3$ & \\
\hline
\end{tabular}

**** $p<0.01 ; * 0.01<p<0.05 ; * 0.05<p<0.10$

women working in this type of industry the observed values exceeded the expected, but not significantly. Most of these workers were employed in concrete factories or in brickyards. About $60 \%$ of these men reported a history of work in dust or variable temperature but only three of 12 women so reported. Foundry workers and male workers in "other" industries showed a decline in FEV , only slightly above that expected from the regression equations. Almost $30 \%$ of male foundry workers reported having worked in dust or in variable temperature in 1968 for more than five years and continued exposure in 1973 (almost $50 \%$ of all reporting such exposure), and $60 \%$ had worked at some time in these exposures.

Another confirmation, that the observed effects of dusts and variable temperature cannot be attributed solely to exposures in foundry, was the regression models calculated for all men except foundry workers. They showed similar effects of exposures as for the total group (for exposure to variable temperature over five years in 1968 and continued in $1973 b=10.9$, $\mathrm{SE}_{\mathrm{b}}=6 \cdot 3$ ).

Non-significant differences between observed and predicted decline in $\mathrm{FEV}_{1}$ mean that the effects of exposures were estimated satisfactorily in this group of workers. In male workers in the building materials and pottery industry the effects of exposures were underestimated. When residuals were calculated separately for the exposed and non-exposed subjects, however, the observed decline in FEV , exceeded significantly (20 $\mathrm{ml} / \mathrm{y}, \mathrm{p}<0 \cdot 10)$ the expected values only in those not reporting exposure. This might be interpreted as an additional underestimation of the exposure by the respondents. The opposite was seen for construction workers reporting exposures - their predicted decline in $\mathrm{FEV}_{1}$ were considerably greater than the observed values.

In most branches of industry the residuals were slightly greater in manual than in non-manual workers.

Table 7 Residual (observed-expected) decline in FEV, by place of work in 1968

\begin{tabular}{|c|c|c|c|c|c|c|}
\hline \multirow[b]{2}{*}{ Place of work } & \multicolumn{3}{|c|}{ Men $\triangle F E V_{1}$ resid $(\mathrm{ml} / \mathrm{y})$} & \multicolumn{3}{|c|}{ Women $\triangle F E V_{1}$ resid $(\mathrm{ml} / \mathrm{y})$} \\
\hline & No & $\overline{\boldsymbol{x}}$ & $S E$ & No & $\overline{\boldsymbol{x}}$ & $S E$ \\
\hline $\begin{array}{l}\text { Mining } \\
\text { Foundry, heavy industry } \\
\text { Chemical industry } \\
\text { Building materials and pottery }\end{array}$ & $\begin{array}{r}9 \\
193 \\
27\end{array}$ & $\begin{array}{r}-4 \cdot 0 \\
1.5 \\
-0.3\end{array}$ & $\begin{array}{r}10 \cdot 0 \\
2 \cdot 6 \\
7 \cdot 1\end{array}$ & $\begin{array}{r}6 \\
75 \\
43\end{array}$ & $\begin{array}{r}-2.0 \\
0.4 \\
0.6\end{array}$ & $\begin{array}{r}15 \cdot 7 \\
2 \cdot 7 \\
4 \cdot 4\end{array}$ \\
\hline $\begin{array}{l}\text { industry } \\
\text { Textile industry } \\
\text { Other industry } \\
\text { Construction } \\
\text { Agriculture, forestry } \\
\text { Transport } \\
\text { Education, research, culture } \\
\text { Other }\end{array}$ & $\begin{array}{r}21 \\
2 \\
101 \\
81 \\
11 \\
41 \\
57 \\
131\end{array}$ & $\begin{array}{r}19 \cdot 5 * \\
-0.7 \\
1.5 \\
-2 \cdot 4 \\
-4 \cdot 7 \\
-7 \cdot 7 \\
-2 \cdot 3 \\
2.0\end{array}$ & $\begin{array}{r}10 \cdot 3 \\
17 \cdot 8 \\
4 \cdot 5 \\
4 \cdot 3 \\
11 \cdot 0 \\
4 \cdot 8 \\
4 \cdot 3 \\
3 \cdot 5\end{array}$ & $\begin{array}{r}12 \\
17 \\
193 \\
60 \\
13 \\
32 \\
120 \\
290\end{array}$ & $\begin{array}{r}17 \cdot 3 \\
0.9 \\
-0.7 \\
-1.4 \\
-2.5 \\
-3.9 \\
3 \cdot 1 \\
-0.4\end{array}$ & $\begin{array}{r}13 \cdot 4 \\
10 \cdot 3 \\
1 \cdot 9 \\
3 \cdot 5 \\
10 \cdot 3 \\
4 \cdot 9 \\
2 \cdot 8 \\
1 \cdot 6\end{array}$ \\
\hline
\end{tabular}

p $<0 \cdot 10$. 
Table 8 Residual (observed-expected) decline in FEV by type of agent present in the workplace at any time before 1981

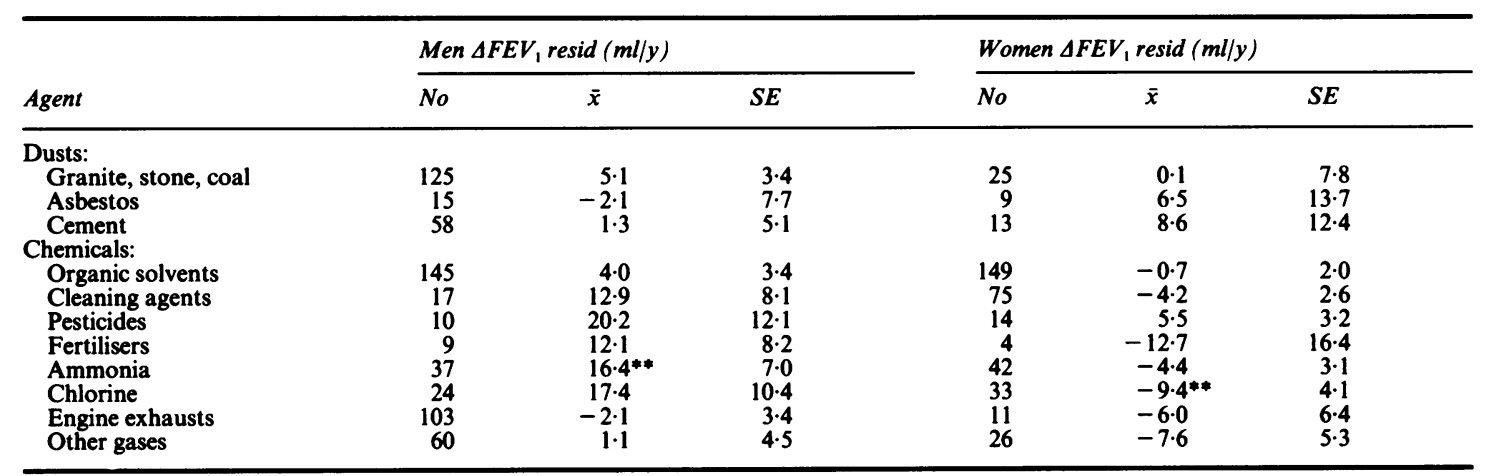

**p $<0.05$.

The residuals of decline in $\mathrm{FEV}_{1}$ were also tabulated according to more specific types of hazards reported in 1981 as ever present in the subject's working environment. A significantly greater than expected decline in $\mathrm{FEV}_{1}$ was found in men reporting exposure to ammonia (table 8). When this factor was included in the regression model, the corresponding coefficient was $17.6 \mathrm{ml} / \mathrm{y}, \mathrm{SE}_{\mathrm{b}}=6.6(\mathrm{p}<0.01)$ with small changes in the values of other coefficients. The mean reported duration of this exposure was 17 years and almost two thirds of those exposed also reported in 1968 or 1973 exposure to dusts or variable temperature. In women reporting exposure to ammonia decrease in the FEV 1 was no greater than expected. The duration of this exposure was similar to the men (15 years) but the proportion exposed to ammonia reporting also other exposures was smaller than in men $(50 \%)$. A faster than expected decline in $\mathrm{FEV}_{1}$ was found also in men reporting exposure to solvents, cleaning agents, pesticides, fertilisers or chlorine. The variability of residuals was large, however, and the observed values of decline in $\mathrm{FEV}_{1}$ were not significantly greater than expected.

\section{Discussion}

Our analysis has shown a significant increase in longitudinal decline in $\mathrm{FEV}_{\mathrm{1}}$ related to occupational exposure. The most pronounced effect on decline in FEV , could be attributed to exposure to variable temperature that was prolonged and lasting over the follow up. The effects of chemicals and irritating gases appeared immediate and even after a short period of exposure ventilatory function deteriorated faster than in those never exposed. No consistent results were obtained with regard to the effect of dusts independent of exposure to variable temperature or chemicals.

Several previous studies have shown the effect of occupational exposures on longitudinal decline of lung function. These studies considered miners, ${ }^{78}$ foundry workers, ${ }^{910}$ workers in chemical plants, grain elevator workers, ${ }^{12}{ }^{13}$ and workers in various factories. ${ }^{14}$ In most cases the subjects were exposed to high concentrations of dusts or fumes in the workplace. Our study covered those of various occupations and working in various types and levels of exposures. Though the longitudinal follow up did not cover the whole group examined in the baseline survey, selection bias was unlikely to distort the representativeness of the subjects as regards the type and intensity of exposure characteristics among Cracow's inhabitants, which are likely to resemble those of inhabitants of other large cities. Our study included not only subjects exposed at the time of the baseline survey, as is the case in most studies performed in industrial settings, but also those exposed only during the follow up period. For women, such exposure to chemicals was found to be the major factor accelerating the decline in $\mathrm{FEV}_{1}$. In studies performed in industrial populations exposures present only in the past are usually not considered. In our study past, prolonged exposure to dusts was related to faster decline in $\mathrm{FEV}_{1}$ in women. The clearest effects, however, were observed for exposures present during the follow up period. This supports the thesis of a causative role of occupational exposures in the pathogenesis of chronic airways limitation.

An apparent weakness of our study is the lack of assessment of the specific composition and intensity of exposure obtained independently from the interview. Even in longitudinal studies performed on industrial populations, however, it is difficult to assess exactly the level of an individual's exposure, though the nature of it is much easier to establish. In part, that problem might bias our results concerning the relation of a decline in FEV, to exposure to dust. In the opinion of the respondents "dusts" are usually interpreted as relatively coarse, noticeable particles and not as fine particles that may be responsible for chest problems. Another result, possibly connected with the assessment of exposure, was an apparently strong effect of 
ammonia. There may be some doubt if it was really specific. It is known that in industrial settings ammonia usually coincides with other chemical hazards that have higher "taste" and "odour" thresholds. In our study group those exposed to ammonia worked in various enterprises where exposure to a number of chemicals was possible, such as a pharmacy, pharmaceutical factory, or rubber factory. In these circumstances workers tend to report the presence of ammonia in the workplace only because it irritates the eyes and upper respiratory tract even in concentrations below the maximal allowable level. Other contaminants, not so easily detectable by workers, may sometimes be more important for deterioration of lung function. ${ }^{15}$

The most striking result of the present study is the significant and consistent relation between decline in FEV $_{1}$ and "variable temperature." In other studies increased decline in $\mathrm{FEV}_{1}$ was found in workers exposed to heat. ${ }^{14}$ In our interview the question concerned not heat but variable temperature (coldheat). This term is more explicit and unequivocal in character than terms such as "dusty environment" and the results in this respect are probably less biased by the lack of an independent assessment of exposure. The effects of this factor are not limited to occupations with evident exposure to heat, such as foundry workers, and may partly relate to outdoor work. The temperature is not high in Cracow in summer (usually below $25^{\circ} \mathrm{C}\left(80^{\circ} \mathrm{F}\right)$ ) but in winter it falls below $-10^{\circ} \mathrm{C}$ $\left(15^{\circ} \mathrm{F}\right)$ and may cause some discomfort. Among those exposed to variable temperature the frequency of acute respiratory infections (pneumonia in men and bronchitis in women) during follow up was slightly greater than in those not exposed $(11 \% \vee 6 \%$, $\mathrm{p}<0.10$ in men and $36 \% v 18 \%, \mathrm{p}<0.05$ in women; exposed five years in 1968 and continuing exposure in $1973 v$ others, respectively). Other analyses of our data (W Jẹdrychowski, annual meeting of European Society for Clinical Respiratory Physiology, Antwerp, 1987), and other studies ${ }^{17}$ have suggested some temporary decrease in $\mathrm{FEV}_{1}$ in people with acute respiratory disease. Both these associations, however, are too weak to explain the relation between rate of longitudinal loss in FEV $_{1}$ and exposure. When exposures and infections were considered jointly in regression equations, only the former were significant with the estimated effects similar to those in table 6 . Possibly variable temperature is a non-specific indicator of an unhealthy working environment. Kauffmann et al could not determine which of two strongly correlated factors - heat or dusts-was the factor producing a deleterious respiratory effect but concluded that dusts were the more important. ${ }^{14}$ Our results, however, suggest that variable temperature may have an important impact on natural history of chronic obstructive pulmonary diseases which should be studied further. The effect of dusty work on decline

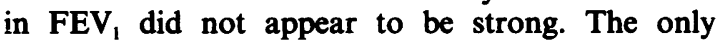
significant effect independent of exposures to variable temperature and chemicals was detected for exposures to dust only in the past among women. Another indication of influence of exposure to fine particles on lung function could be the results obtained for workers in the building materials and pottery industry where we observed an accelerated decline in FEV 1 . The few workers in industries with similarly high levels of air pollution with fine particles, not necessarily connected with exposure to variable temperature, could be a reason why we did not detect a more pronounced effect of dusts. The other reason may be the problems of assessing dust exposure, mentioned above.

The most pronounced effect of chemicals and irritating gases was noticed for relatively short exposures, present mainly in the follow up period. This pattern of association may partly result from a self selection bias: workers affected by the exposure tend to change the workplace after shorter exposure. The remaining workers seem to be less susceptible (or an agent less hazardous): the relatively high baseline FEV level in those exposed for a longer period seems to support such a hypothesis.

The magnitude of estimated significant effects of exposure to chemicals or variable temperature was close to the effects of cigarette smoking. The relations between the estimated regression coefficients do not depend on the method of adjustment (with mean FEV, level or with age) and is concordant with the results obtained in workers in the Paris area. ${ }^{1418}$ The deleterious influence of smoking on lung function should still, however, be considered as relatively more important since the number of smokers ( 329 men and 174 women) was several times greater than numbers of subjects in particular occupational exposure groups and, in men, many smokers with the fastest decline in FEV 1 stopped smoking during the follow up period. ${ }^{4}$

Supported in part by Grant P-05-109-N from National Heart, Lung and Blood Institute, Bethesda, Maryland, USA.

Requests for reprints to: Michat Krzyżanowski, National Institute of Hygiene, Chocimska 24, 00-791 Warsaw, Poland.

\section{References}

1 Morgan WKC. Industrial bronchitis. $\mathrm{Br} J$ Ind Med 1978;35: 285-91.

2 Speizer PE, Tager IB. Epidemiology of chronic mucus hypersecretion and obstructive airways disease. Epidemiol Rev 1979;1:124-41.

3 Becklake MR. Chronic airflow limitation: its relationship to work 
in dusty occupations. Chest 1985;88:608-17.

4 Krzyżanowski M, Jęrychowski W, Wysocki M. Factors associated with the change of ventilatory function and the development of chronic obstructive pulmonary disease in 13 year follow up of the Cracow Study. Am Rev Respir Dis 1986;134:1011-9.

5 Sawicki F. Chronic nonspecific respiratory diseases in Cracow. Epidemiological Review (Przeglad Epidemiologiczny) 1972;26:229-50.

6 Krzyżanowski M, Wysocki M. The relation of thirteen-year mortality to ventilatory impairment and other respiratory symptoms. The Cracow study. Int J Epidemiol 1986;15:56-64.

7 Love RG, Miller GB. Longitudinal study of lung function in coal miners. Thorax 1982;37:193-7.

8 Attfield MD. Longitudinal decline in FEV 1 in United States coalminers. Thorax 1985;40:132-7.

9 Brinkman GL, Block DL, Cress C. Effects of bronchitis and occupation on pulmonary ventilation over an 11 year period. J Occup Med 1972;14:615-20.

10 Pham QT, Mastrangelo G, Chan N, Hatuszka J. Five year longitudinal comparison of respiratory symptoms and function in steelworkers and unexposed workers. Bull Eur Physiopathol Respir 1979;15:469-80.

11 Jẹdrychowski W. A consideration of risk factors and development of chronic bronchitis in a five-year follow-up study of an industrial population. $J$ Epidemiol Community Health 1979;33:210-4.

12 Enarson DA, Vedal S, Chan-Yeung M. Rapid decline in FEV, in grain handlers. Relation to level of dust exposure. Am Rev Respir Dis 1985;132:814-7.

13 James AL, Cookson WOCM, Buters G, et al. Symptoms and longitudinal changes in lung function in young seasonal grain handlers. Br J Ind Med 1986;43:587-91.

14 Kauffmann F, Drouet D, Lellouch J, Brille D. Occupational exposure and 12-year spirometric changes among Paris area workers. Br J Ind Med 1982;39:221-32.

15 Jedrychowski W, Flak E, Bem S, Debowski Z. The effect of prolonged occupational exposure to the low concentration of nitrogen oxides in combination with ammonia. Pneum Pol (in press).

16 Teculescu DB, Pham QT, Locuty J, Kuntz C. Episode infectieux respiratoire banal et obstruction des voies aériennes périphériques. Bull Eur Physiopathol Respir 1983;19:393-9.

17 Neukirch F, Kauffmann F, Korobaeff M, Liard R. Common cold with cough on the day of examination: a factor that should be taken into account in epidemiological studies on pulmonary function. Int J Epidemiol 1985;14:635-6.

18 Kaufimann F, Drouet D, Lellouch J, Brille D. Twelve years spirometric changes among Paris area workers. Int J Epidemiol 1979;8:201-12. 